\title{
Gastronomic Tourism: Attitudes, Motivations and Satisfaction of the Visitor in Cantons of Tungurahua, Ecuador
}

\author{
Tannia Elizabeth Huertas López ${ }^{1}$, Yenis Cuétara Hernández ${ }^{2}$, \\ Leonardo Manuel Cuétara Sánchez ${ }^{3}$, Milton Marino Villarreal Pastaz ${ }^{4}$ \\ ${ }^{1}$ School of Business Administration, University of the Armed Forces ESPE-ESFORSE, Ambato, Ecuador \\ ${ }^{2}$ Career of Education in Experimental Sciences, National University of Education, Azogues, Ecuador \\ ${ }^{3}$ Faculty of Business Administration and Economics, Technical University of Manabí, Manabí, Ecuador \\ ${ }^{4}$ Specialists in Non-Destructive Testing, ESPEND, Quito, Ecuador \\ Email: thuertas@hotmail.es
}

How to cite this paper: Huertas López, T.E., Cuétara Hernández, Y., Cuétara Sánchez, L.M. and Villarreal Pastaz, M.M. (2019) Gastronomic Tourism: Attitudes, Motivations and Satisfaction of the Visitor in Cantons of Tungurahua, Ecuador. American Journal of Industrial and Business Management, 9, 699-719.

https://doi.org/10.4236/ajibm.2019.93047

Received: February 27, 2019

Accepted: March 23, 2019

Published: March 26, 2019

Copyright $\odot 2019$ by author(s) and Scientific Research Publishing Inc. This work is licensed under the Creative Commons Attribution International License (CC BY 4.0).

http://creativecommons.org/licenses/by/4.0/ cc) (i) Open Access

\begin{abstract}
Gastronomic tourism is a new form of cultural tourism that seeks to satisfy the demand of a market segment related to the supply of food products. Regarding this purpose, Ecuador presents a mega diversity of flavors and natural products that reflect natural and cultural offering, particularly in gastronomy which has merged the Ecuadorian ancestral flavors with the techniques of contemporary cuisine. The purpose of this article is to characterize the segment of tourists and excursionists who are motivated to visit the cantons of Ambato, Baños and Mocha located in the province of Tungurahua due to their customs and gastronomic traditions. The methodology used is based on the philosophy of gastronomic marketing, especially, in the characterization of a set of socio-psychological variables related to the motivation and satisfaction of food and drink offerings in the selected cantons, by applying multivariate statistical and descriptive analysis tools. Among the conclusions of the study it is emphasized the need to develop a management strategy for the improvement in the visitor service delivery, the identification of new attractions, health conditions of the premises and service areas, as well as the timely marketing and promotion of the current gastronomic offering.
\end{abstract}

\section{Keywords}

Visitor's Profile, Gastronomic Tourism, Gastronomic Motivations, Tungurahua Gastronomy

\section{Introduction}

Gastronomic tourism is considered a means to recover the traditional food of 
each area and has acquired, worldwide, greater importance during the last decades, because it has become a key piece for the positioning of regional foods. Since the last half of the 20th century there has been a structural change in the way food consumers consider food (Williams and Dossa, 2003) cited by Millán (2012) [1], and gastronomic tourism arouse attention of scholars from different parts of the world after the World Gastronomic Tourism Congress, held by the World Tourism Organization (UNWTO) in Cyprus in 2000.

Gastronomic tourism as a tourist phenomenon has developed considerably in Ecuador and has become one of the most dynamic and creative segments of tourism, not only because of the financial effect it gives as a result, but also because of the social and cultural interaction that is achieved.

There are multiple and varied effects for the local community that lives in a tourist destination, for example, it improves the quality of life, it creates sources of employment, it stimulates the conservation of cultural traditions, natural resources and the environment, the diffusion and the consumption of foods that are part of regional gastronomy. Tourists who visit a certain tourist destination can make innumerable decisions during their trip that may modify the activities to be carried out, however, during their stay they cannot stop feeding.

Both, destinations and tourism companies, have realized about the importance of gastronomy to diversify tourism and stimulate local, regional and national economic development (OMT, 2012), cited by Leal (2013) [2].

Since its inception, gastronomic tourism has been a type of tourism in high demand and as part of tourism is a source of income for cantons with certain potential in this type of tourism activity favoring the growth of income in small and medium enterprises with gastronomic offer.

Gastronomy is an essential part of a trip, but it is not just eating or feeding, it means entering the culture of the destination in which it is located, therefore, the gastronomy of a place becomes an attraction of the tourist destination that is being visited. Then gastronomy is a route of tourism development, able to diversify and complement the offer of a destination expanding its marketing possibilities and extending its production and relationships with other economic sectors. When talking about tourism from the perspective of gastronomy, a distinction must be made between those tourists whose motivation to travel is not properly gastronomy and its enjoyment, and those that include gastronomy among the motivations for traveling.

Within this last group, there are visitors who include gastronomy among their objectives and within these category two subgroups can be differentiated, as expressed (Torres, 2013) [3]. Those that consider gastronomy a main motivation and that forms part of what is called specific tourism; and those persons and tourists for whom gastronomy constitutes a secondary and/or complementary motivation.

In the world of tourism there are influential destinations whose brand image is linked to gastronomic values at different levels of intensity. In this way, customer's satisfaction, to fulfill their expectations, will allow the destination to in- 
crease their loyalty by increasing their intention to repeat their stay. Thus, "quality gastronomy is a decisive factor in satisfaction, as it produces an unforgettable memory in the experience lived by tourists", as indicated in the report of the World Tourism Organization (2012) [4].

Gastronomy is thus consolidated as a key element to diversify the tourist offer and stimulate local, regional and national economic development with sustainability values based on the territory, the landscape, the sea, local products and authenticity; all of them on the same line of current trends in gastronomic consumption.

The gastronomic tourism segment (OMT, 2012) [4]; is especially important for rural communities, according to the Secretary General of the Organization, Taleb Rifai, who has a great competitive advantage when serving traditional dishes due to their proximity to food producing lands. In this way they can generate income and jobs, in addition to contributing to the maintenance of other sectors of the local economy such as agriculture.

In the characterization of the profile of the visitor that demands this type of product in rural cantons of the province of Tungurahua, the research has been structured in three very well differentiated sections, whose methodology is summarized in a first step, where the concept of gastronomic tourism is defined based on its historical background and its evolution. Then, a second step, where the relative importance of this type of tourism is described based on certain social, cultural and economic factors that, in a certain way, justify its incidence in the communities where it is developed.

Finally, among the main theoretical and/or empirical contributions of this research, it must be highlighted the characterization from the quantitative approach of the main identified variables in the gastronomic tourist profile analysis. This characterization constitutes a crucial factor and is the basis for the permanence of this type of tourism in the tourist market. Besides, this research describes the study of the survey results and their corresponding data processing through the integration of some descriptive and multivariate statistics tools. The findings have permitted to know the gastronomic tourist behavior and their evaluation criteria of the offering for this type of product and services in the selected cantons. Additionally, the main visitor's motivations as well as the level of satisfaction with the gastronomic services offered by each local supplier are identified in different modalities such as restaurants, food court and tourist centers respectively. In conclusion, it is important to mention that gastronomic tourism in Ecuador, is a strategy to diversify tourist products and services offerings in different destinations in the country (Huertas, T., 2016) [5].

\subsection{Gastronomic Tourism: Definition and History}

Tourism is defined by the World Tourism Organization (UNWTO) as a social, cultural, and economic phenomenon, related to the movement of people outside their usual place of residence for a specific reason (UNWTO, 2005-2007) cited by González H., S. (2014) [6]. 
The UNWTO, World Tourism Organization, as indicated by the University School of Tourism of Murcia (2012) [7], has developed, among its functions, concepts that are valid for everybody to make the statistics in the same way and therefore, become comparable. Hence, a few years ago, the following definition was developed to achieve the purpose above: "The activities carried out by people during their trips and stays in places other than their usual environment for a consecutive period of less than one year for leisure purposes, for business and other reasons".

The specialized bibliography classifies tourism according to the attitude of the traveler: active or passive tourism; according to the time used for the displacement or the stay: tourism of stays or residential and itinerant tourism; according to the traveler's income: elite; mass, and social, and lastly, according to the reason: gastronomic, religious, sun and beach, business, among others.

When taking into account the object of study of the present investigation, it is necessary to indicate that within cultural tourism various subsegments are managed, among which family tourism (visit to family and friends), religious tourism (pilgrimages or visits to religious places or temples) stand out, ethnic tourism (in places where a particular ethnic group resides) and gastronomic tourism (trips to places highlighted by its cuisine) (Quesada Castro, 2007) cited by Flores (2013) [8].

Beyond tourism, gastronomy can reveal the structural elements of a country and a culture. That is why, from the French initiative for the recognition by UNESCO of the "gastronomic review of Français" as Intangible Heritage of Humanity (2010) cited by Clave (2012) [9], it can be deduced that gastronomy has become a cultural product in relation to which there is a planetary competition. Indeed, this initiative can be interpreted as a response strategy of a dominant national cuisine for a long time and proud of a culinary heritage long admired by the arising of other national schools, particularly Spanish cuisine, a more mediatically structured and more efficient one.

On the other hand, according to the classification by the type of motivation, gastronomic tourism is focused on a very specific resource/attraction, which is gastronomy, the main motivation of travelling. The people who carry out this type of tourist activity, do not dedicate themselves to visit certain restaurants with the intention of satisfying their food needs, but it is something much more complex, as defined by Serrano, E. (2013) cited by González H. S. (2014) [6], “it is an experience that allows us to enter into the knowledge of the product, of the people, of the environment, culture and heritage". Gastronomic tourism is related to a trip that includes activities that have a relation with food or drink, with primary products and with the service providers located in the community.

It is known that food can be analyzed from several perspectives, on the one hand, "it fulfills a biological function by supplying the body with the substances indispensable for its subsistence" (Schlüter, 2006), it is also visualized as a "voluntary process, conscious and educable" (Martínez Jasso and Villezca Becerra, 2005). From the cultural context, "food is a factor of cultural differentiation that 
allows all members of a culture, regardless of their level of income, to show their identity" (González Turmo, 1999), cited by Flores (2013) [8]. Another definition referring to the theme expresses that "Food is the satisfaction of physical needs and gastronomy allows sublimate this function and makes the act of eating a pleasure for the senses and the intellect" (Silva, E., 2012) [10].

Referring to this aspect, food was always part of the trips due to a simple need for biological order. Gastronomy, as a sign of its cultural richness, becomes an irrefutable resource in the tourist field and it is, unquestionably, this type of product that awakens the interest of the consumer, forming part of the trilogy in tourism such as food, transportation and lodging (Palais, R., 2012) [11].

However, from the tourism context, feeding is also part of the tourist experience of all visitors when making use of the food services of a specific locality (Nunes dos Santos, 2007), it also represents a way of linking the people and the territories they visit (Clemente Ricolfe et al., 2008), also cited by Flores (2013) [8]. The supply of food services, including other services such as transportation and lodging, are essential for the visitor's subsistence, and in the specialized literature they are called "support services", as well as recreation, entertainment and shopping, are services intended to stimulate the desire of customers, as described in (Chan, 2015) [12].

As described in the consulted literature, representative activities of the gastronomic tourism, the visit to markets, houses of residents in the rural area, stores of handicrafts and ecological products, participation in gastronomic fairs, festivals, workshops of preparation of typical dishes should be considered, among others. Consequently, this type of tourism can also be defined as holiday or cultural tourism.

According to these ideas, gastronomic tourism is based on the conception of the need to eat, the main motivation of tourists in this type of trip, in addition to satisfying one of the needs of self-realization according to the Maslow pyramid, which indicates that the tourist, when traveling to a certain place, seeks to enjoy gastronomy, feel self-fulfilling when satisfying their desires, because their needs have already been met.

Consumers today seek not only to acquire or consume products and services, but also to live pleasant experiences (Rieunier, 2004; Bellos \& Kavadias, 2011) cited by Gomes T. and Gomes de Souza (2013) [13].

For all the above, it is understood as gastronomic tourism that trip whose main motivation is the tasting of elaborated dishes or typical local products, as well as, the visit and knowledge of the elaboration processes or any other event related to food and drinks.

According to Mitchell and Hall (2003), cited by Montesinos, A. (2012) [14], it is important to first differentiate the tourists that feed because they are outside their usual place of residence from those whose destination selection is directly related to the gastronomy.

In this sense to the definition proposed by (Hall and Sharples, 2003), cited by Montesinos, A. (2013) [14]; gastronomic tourism is: the visit to primary and 
secondary producers of food, gastronomic festivals, restaurants and specific places where the tasting of dishes and/or the experimentation of the attributes of a region specialized in the production of food is the main reason for making a trip.

For Vázquez de la Torres (2013) [15], gastronomic tourism is a means to recover the traditional food of each area. During the last half of the 20th century there has been a structural change in the way of validating food by the tourists, it is an instrument that will help the positioning of local foods and has become a key stone in the structure of the tourist offer of different destinations in the international context.

According to Ávila A. R. (2012) [16], gastronomic tourism is defined as: all trip made to experience new foods and drinks particular to the region, know its ingredients and even learn to prepare them. In addition to discovering new sensations and culinary experiences, that is what we call gastronomic tourism.

On the other hand, Montesinos, A. (2013) [14], gastronomic tourism is defined as: people who, during their trips and stays, carry out activities based on material and immaterial gastronomic cultural heritage in different places other than their usual surroundings, for a period of time of consecutive time less than a year with the main purpose of consuming and enjoying products, services and gastronomic experiences in a priority and complementary manner.

\subsection{The Contextualization of the Behavior of Gastronomic Tourism}

The behavior of the consumer is the study of people, groups or organizations and the processes that are then followed to select, get, use and dispose of products, services, experiences or ideas to satisfy needs and the impacts that these processes have on the consumer as indicated by (Hawkins, Best \& Coney, 2008) [17] and López (2016) [5].

Kotler\& Armstrong (2008) [18], in its book Fundamentals of Marketing define the behavior of the consumer as: "the behavior of purchase of final consumers, individuals and households that acquire goods and services for their personal consumption".

The attitudes identified in the consumer (as indicated in Survey of Tourism Situation of Andalusia, 2018: 6) [19], are those expressions of people that state their favorable or unfavorable direction of their feelings towards a product, service or idea which is intended.

As to attitudes, some essential characteristics should be pointed out:

- Presence of an objective stimulus. To know the attitude, it is necessary to show an object or a stimulus to the consumer to give guidance and advice to him.

- It deals with the result of a learning process which is the result of a repetitive experience of the individual towards an established object.

- The attitudes vary according to the consumer's environment. An example would be a person with an intolerance to lactose. In this way he or she must 
buy milk without lactose even though it is more expensive than any other type of milk.

In other studies made by the Metropolitan District of Quito, about the characterization of receptor tourism (Quito Turismo, 2011) [20], in the analysis of total expenses variable in the destination, it is concluded that the goods or services consumed such as lodging, gastronomy, transportation and shopping are the four principal areas of expenses of the non-residential tourist who visits the city with purposes of recreation, while the consumption preferences of the tourist that arrives with the objective of visiting the family or friends are centered in shopping and gastronomy respectively.

In both cases, it is outstanding the increasing importance of gastronomic and transportation expenses as well as the one of minor importance which is lodging, so, this is a sign of the importance of gastronomic offer within the offer environment of goods and services in Quito destination.

When checking bibliography written by different authors, some studies made about the topic of gastronomic tourism were consulted including the characteristics of the tourist's profile. Some of the authors are (Vienha, 2004; Torres Bernier, 2003; Fields, 2002; Hall et al., 2003) cited by Olivera (2016) [21].

Researchers agree about three essential aspects related to the variables that identify the profile of the gastronomic visitor:

- Gastronomic tourists have high medium expenses, higher than the ones presented by generic tourists, they also generally have a high cultural level associated to a good economic situation. Usually there are just a few sensible to prices so they become excellent restaurant clients because they do not care about expenses to try new flavors.

- The one who travels for economic reasons is, in most of the cases, demanding enough and cares about the quality and authenticity of the gastronomy that is offered to him. This is a logical consequence because if the main motivation is gastronomy, the tourist will not accept to be disappointed. However, while the most generalist tourist may not pay a close attention to a less quality meal, the gastronomic tourist will not do this and will show his displeasure.

- In relation to promotion, this will be made in a different way than the one that is usually made for generalist public, considering gastronomic tourism as a market niche. Promotion does not have to be very intense since here is a great interest by these tourists and they usually get their own information, whether to be in tourist guides, magazines or surfing the web or by other means of information. The "mouth to mouth" is also very important.

On the other hand, Prom Perú (2008) [22], has published a research referred to the determination of the tourist's community rural profile, considered as that type of tourism that "involves all tourists, recreation and complementary activity which is developed in a rural area in a sustainable way and with the participation of rural and/or native communities" (Micentur, 2007) [23]; among the research variables already identified, reference is made about the following ones: previous 
experience when visiting native communities, motivation for making community tourism, attitudes assumed by foreign tourists when visiting native communities, motivations for travelling to Peru, sources of information to travel to Peru, experience to travel to Peru, travel Group with which the tourist visited any of the communities, activities made in native communities, buy of any good or piece of craftsmanship in the native communities, overnight stay in native communities, expenses of a tourist in Peru, evaluation of services in country/native communities, competence of Peru in rural community tourism, recommendation of Peru as a destination for community rural tourism, socio-demographic profile, among others, which will contribute in a way to design the instrument for the characterization of the profile of the gastronomic tourist who visits Ambato, Baños y Mocha cantons in the province of Tungurahua.

When concluding the analysis of the most relevant aspects defined in the development of the theoretical frame, the description of the elements of the methodology proposed are then described.

\section{Methods and Procedures}

When carrying out this study, methods were used that allowed to get reliable data, starting with instrumentation of descriptive investigation which made easier the description of the market segment which is investigated, to analyze the collected information and lastly to make the interpretation of the results already obtained. In relation to the above mentioned the following methodological considerations have been followed in the conformation of the research technical specifications:

- Universe: conformed by local clients included in the age group younger than 20 and older than 36, who made any type of gastronomic activity in points of sale of typical meals, restaurants, meal courtyards and touristic Stops respectively.

- Geographic area: Ambato, Baños and Mocha cantons respectively.

- Technique: personal direct interview to local visitors.

- Instrument: structured and standardized survey with open and close questions.

- Type of sampling: no probabilistic, in quota under the researcher's criterion.

- Points for sampling: the surveys were applied in points of sale of typical food, restaurants, courtyards, and touristic Stops respectively identified in the object of study.

- A sample size of 282 visitors is determined from the proportional allocation method using the formula (Pat Fernández, 2012) [24], coming from Riobamba, Ambato, Machachi, Pelileo, Latacunga, Tisaleo, Salcedo, Quero, Baños, Cevallos y Patate, respectively, according to the mathematical expression: $n=Z^{2} p q N / \mathrm{e}^{2}(N-1)+Z^{2} p q$, where:

$n=$ sample size,

$Z^{2}=$ confidence level,

$p=$ proportion of visitors, 
$q=$ proportion of non-visitors,

$N=$ average population of visitors in each of the cantons under study and,

$\mathrm{e}^{2}=$ error of the results with respect to the population participating in the investigation.

- The level of confidence used was 95\%, the proportion $p=q=0.5$ and the allowed error selected is $5 \%$.

- Date of work in the field: from April 30th to June 30th, 2017.

- Implementing institution: Regional Autonomous University of Los Andes, students of Second and Third Semester of Tourism Course.

In order to establish the size of the sample, non-probabilistic sampling by quota has been selected, which is widely used in surveys about electoral opinion, market research or similar, as described by Hernández (2006) [25].

The sampling is of a non-probabilistic type, where, according to what the frame shows (tourists of national origin who visit the Mocha canton), all visitors do not have the same opportunity to be selected at random. On the other hand, the technique used to obtain the information was the written survey to be answered by the selected persons, the average time of application was twelve minutes, so the way in which the instrument was applied was personal interview to a total of 282 visitors.

The processing of the data collected through the survey was developed in three stages: the tabulation of the data according to the questions asked, the calculation of the answers (percentages), with the help of the statistical program IBM-SPSS Statistics v. 20, and the analysis, interpretation and description of the results reflected in tables and graphs, regarding the theoretical framework and the research background.

The application of the analytical method allowed to analyze the nature, peculiarities and the relationship that exist between the elements that make up the study area through the observation, description and classification of available information.

Regarding the primary research sources, it should be noted that the information should be considered within the tourist activities system, since, in one way or another, it is an essential part of the tourism production process (Bermúdez, I. et al., 2011) [26].

The information that has been collected was obtained from direct sources, through the application of a survey to tourists and local visitors who attend to meet certain food needs in each of the points of sale of gastronomic offer.

\section{Results and Discussion}

In order to identify the profile of the gastronomic visitor it is necessary to have some guidelines that allow establishing their reference pattern. In the review of the specialized literature a set of aspects are described, among which demographic characteristics, lifestyle, motives, personality, values, beliefs and attitudes, perception and learning can be mentioned.

Regarding the demographic characteristics, in this case the consumer can be 
described according to their physical characteristics (age, gender, among others), their social characteristics (marital status, social class, others), or their economic characteristics (income, education, employment, among the most important ones).

In the literature it is stated that the reasons represent the purpose of a customer to acquire a product or service and these may be of the following types: physiological, safety, belonging, self-esteem and personal fulfillment.

Other elements to be considered are the personality of the consumer, in terms of values, the result of the interaction of the consumer with the environment in which he has lived is specified, the beliefs factor is integrated to the own or foreign experiences that the consumer must develop from opinions or judgments that he considers to be true, attitudes are feelings of liking or disliking towards some type of product or service, perception is defined as the process by which information of the environment is captured, interpreted and recalled, is one of the reasons why consumers react differently to a stimulus, product or service.

In another bibliography entitled "How to structure the profile of a consumer" according to Huertas (2015) [27], it is described as variables to be studied, the lifestyle, establishing the kind of products and services acquired by the local consumer according to their tastes and preferences, the motivations are determined by the stimuli that encourage the consumer to perform an action, generate the impulse to do something, the personality is based on a set of characteristics or patterns of emotions, feelings and thoughts related to behavior, in addition to the values (as the quality that a consumer or group of consumers attributes to a product or service), beliefs is the state in the mind of a consumer which considers as true the knowledge or experience of some product or service, the perception that allows through the senses to receive, to elaborate the information of his environment and that of himself. Lastly, learning is the process that allows skills, abilities, knowledge, behaviors and values to be acquired or modified in the study.

Lastly, another publication referring to the problematic which is the object of study "Profile and characteristics of the tourist, Annual report about tourism in Andalucia, 2006", points out, among the profile variables included in the research, the following ones: age, gender, occupation, type of lodging, travel with how many persons, if he/she organizes the travel, motivation, how many times he/she has visited the destination, how he/she knew about the tourism offer in the destination, what validation he/she has about the relation quality-price among others.

\section{Characterization of the Profile of the Gastronomic Visitor}

In order to fulfill this specific objective, an instrument is prepared that allows to characterize the profile of the gastronomic tourist, therefore, the design of the survey carried out, aims to collect information about the characterization of the profile of the consumer that systematically attends the activities offered by the small and medium production and service companies located in the cantons of Ambato, Baños and Mocha respectively, at the same time, it is intended to iden- 
tify their main motivations for moving within each of the selected territories. The following types of questions will be used for the design of the survey: closed or dichotomous, of multiple choices and open or free response questions.

For the collection of information, the non-random quota selection method is applied, as it has been consulted in the specialized literature, already explained in the previous section, using the instrument for the collection of information and subsequent processing as shown in Table 1, where all the variables that describe the behavior of the profile of the gastronomic visitor are described, which travel from the cantons of Ambato, Baños and Mocha respectively.

After processing the collected data, the profile of the gastronomic visitor is detailed below (Huertas, 2016) [28], where the following criteria or segmentation variables are considered. They may be geographic, demographic and cultural ones, proper of the respondents. At another time, in relation to the responses of the consumers to a specific product, sought benefits, moments of use are identified as described below:

- Gender: male sex predominates in the gastronomic offer, with $51.8 \%$ participation.

- Age: an indistinct behavior is observed between the ranges of 21 - 25 years old (27\%) and between 26 - 30 years old (25.2\%) of the tourists and visitors who demand this type of gastronomic offer.

- Provenance: the highest percentage corresponds to Mocha canton with (45\%), then Ambato with (27\%), Pelileo with (6.7\%), Quero with (5\%) and Riobamba with (3.9\%), respectively.

- Academic training: there is a diversity of training levels in tourists, with a preponderance of high school (28.7\%), University level (26.6\%) and junior high school (22\%).

- Occupation: the statistical results that characterize the variable, indistinctly tourists and structured visitors are identified as follows: employee (41.8\%), student (28.7\%), professional (22\%) and entrepreneur (7.4\%) out of the total number of respondents who participate in the offer of this type of product and gastronomic service.

- Travel with: Out of the respondents traveling with their family (47.9\%) travel with their family, children (11.7\%), traveling alone (10.6\%) and with their partner $(10.3 \%)$, respectively.

- Number of persons accompanying the main tourist: among 3 and 4 persons (50\%), up to 2 persons (28\%) and more than 5 persons in the accompanying group (27\%) out of the total of participants in the research.

- Frequency of visit to the attraction: it has been confirmed according to the respondents that sometimes the category has the value of (57.1\%), usually it has the value of (19.5\%) and very seldom (18.8\%) out of the total number of the attractions inventoried in the study.

- Means of information related to the attraction: the behavior of this variable is described as: recommendations made by the family or friends $(48.8 \%)$, publicity (14.9), television (8.5) and web services (8.2\%). 
Table 1. Synthesis of the performance of representative variables associated with attitudes, motivations and satisfaction of the visitor in the cantons of Ambato, Baños y Mocha.

\begin{tabular}{|c|c|c|c|c|c|}
\hline \multicolumn{2}{|r|}{ Variables } & \multirow{2}{*}{$\begin{array}{c}\text { Percentages } \\
18.8\end{array}$} & \multicolumn{2}{|c|}{ Variables } & \multirow{2}{*}{$\begin{array}{c}\text { Percentages } \\
4.3\end{array}$} \\
\hline & Up to 20 years & & & Forever & \\
\hline & Between 21 to 25 years & 27.0 & & Usually & 19.5 \\
\hline \multirow[t]{3}{*}{ Age } & Between 26 to 30 years & 25.2 & Frequency of visit & Sometimes & 57.1 \\
\hline & Between 31 to 35 years & 14.5 & & Hardly ever & 18.8 \\
\hline & More than 36 years & 14.5 & & Never & 0.4 \\
\hline \multirow{4}{*}{ Gender } & Female & 48.2 & & $\mathrm{TV}$ & 8.5 \\
\hline & Male & 51.8 & & Radio & 6.7 \\
\hline & Ambato & 27.0 & & Advertisements & 7.1 \\
\hline & Mocha & 45.0 & Media consulted & Newspapers & 7.8 \\
\hline \multirow[t]{5}{*}{ Place of residence } & Pelileo & 6.7 & & Advertising & 14.9 \\
\hline & Quero & 5.0 & & Internet & 8.2 \\
\hline & Others & 14.6 & & Recommendations & 46.8 \\
\hline & Primary & 8.5 & & Purchases & 19.5 \\
\hline & High school & 22.0 & & Recreation & 13.8 \\
\hline \multirow[t]{5}{*}{ Academic training } & Bachelor & 28.42 & Keasons for tne trip & Gastronomy & 50.4 \\
\hline & Technique & 14.2 & & Other motivations & 16.3 \\
\hline & University & 27.0 & & Nature & 16.3 \\
\hline & Businessman & 7.4 & & Food and drinks & 29.4 \\
\hline & Professional & 20.2 & $\begin{array}{l}\text { Offers integrated to the } \\
\text { gastronomy }\end{array}$ & Quality environment & 10.6 \\
\hline \multirow[t]{6}{*}{ Job occupation } & Student & 28.7 & & Recreation & 11.7 \\
\hline & Pensioner & 1.8 & & Other & 31.8 \\
\hline & Employee & 41.8 & & Very satisfied & 17.7 \\
\hline & Single & 10.6 & & Satisfied & 64.5 \\
\hline & With family & 47.9 & Level of satisfaction & Acceptable & 15.6 \\
\hline & With his kids & 11.7 & & Dissatisfied & 1.8 \\
\hline \multirow[t]{5}{*}{ Trip composition } & With your partner & 10.3 & & Very unsatisfied & 0.4 \\
\hline & With friends & 8.2 & & Up to $\$ 10.00$ & 8.2 \\
\hline & With relatives & 7.4 & Average expense & Between $\$ 11.00$ - $\$ 15.00$ & 30.1 \\
\hline & With companions & 3.9 & budget & Between $\$ 16.00-\$ 20.00$ & 27.0 \\
\hline & Until two & 28.0 & & More than $\$ 21.00$ & 34.8 \\
\hline \multirow[t]{2}{*}{ Number of people } & Three to four & 50.0 & I would recommend & Definitely & 91.1 \\
\hline & More than five & 22.0 & the gastronomic appeal & Possibly & 8.9 \\
\hline
\end{tabular}

Source: own elaboration based on the output report of the statistical program IBM-SPSS Statistics v. twenty.

- Motivations to visit the attraction: preferences are identified in the following way: gastronomic offer (50.4\%), buying of food (19.55), recreation (13.8\%), peace and quiet (5.7\%), and lastly, culture (3\%), all of which constitute the main motivations from the demand to have access to the different cantons.

- Principal offers as tourism attraction: the gastronomic client and other visi- 
tors decide about the following offers to satisfy their necessities of recreation and leisure: food and beverage offer (29.4), nature (16.3), recreation and leisure (11.7), quality of natural environment (10.6\%), relation quality-price (6\%) and lastly attention to clients (5.3\%).

- Satisfaction with the offer of services in the gastronomic attraction: in the analysis of the satisfaction variable it is observed that the gastronomic client and other visitors value the offer of food and beverages satisfactorily in $(64.5 \%)$, the category very satisfied $(17.7 \%)$, the other classification of neither satisfied, nor dissatisfied (15.6\%) and lastly dissatisfied tourists (1.8\%), in which satisfaction is expressed in a general sense, due to the quality of the gastronomy service, without ignoring that other attributes of the offer and services in the canton should be improved.

- Budget of expenses: In relation to this variable under study, the results of the statistical processing indicate that both tourists and visitors spend more than $\$ 20.00$ in (34.8\%), in the range between $\$ 11.00$ - \$15.00 (30.1\%), and between $\$ 16.00$ - \$20.00 (22\%), then the willingness to spend for the consumption of food products and services offered in the canton can be observed.

- Would they revisit the gastronomic tourism attraction? Out of the total respondents, (91.1\%) answered definitiveness and on the other hand (8.9\%) possibly, this last figure indicates their unwillingness to repeat this experience again.

Finally, among the suggestions issued by tourists and visitors in the cantons of Ambato, Baños and Mocha, with the aim of improving the gastronomic offer, they are described in the following Table 2.

In order to know the main recommendations issued by visitors regarding the gastronomic offer, the following are identified: to improve customer service provision (15.6\%), to identify new attractions to incorporate into the new tourist and gastronomic offer (14.2\%), the relevant commercialization and promotion of the current gastronomic offer (10.6\%), the improvement of accessibility to the gastronomic sales points, restaurants, patios of meals and whereabouts $(7.1 \%)$, the proper management of healthiness of local and gastronomic area $(10.3 \%)$ and the necessary citizen security so required by our customers and visitors in the canton $(6 \%)$ respectively.

The following aspect deals with the behavioral analysis of some socio-psychological variables identified in the research. The analysis was developed by applying the results of the contingency tables as well as the Pearson's Chi-square test. This process helped to determine the significance of the relationship between the gender variables and the motivation to visit and try the gastronomic delights, considering the classification of the budget availability of expenses in the low, medium and high categories respectively. As shown in Table 3 , the following categories have been included in the analysis, for example: food purchase, culture, health, safety, recreation, nature, price and transport among others. 
Table 2. Suggestions issued by tourists and visitors in the cantons of Ambato, Baños and Mocha respectively.

\begin{tabular}{|c|c|c|}
\hline & Variables & Percentages \\
\hline \multirow{15}{*}{$\begin{array}{l}\text { Improvement of the } \\
\text { gastronomic offer }\end{array}$} & Customer Support & 15.6 \\
\hline & $\begin{array}{c}\text { Tourist attractions integrated with } \\
\text { gastronomy }\end{array}$ & 14.2 \\
\hline & Marketing and promotion & 10.6 \\
\hline & Accessibility & 7.1 \\
\hline & Cleaning and hygiene & 10.3 \\
\hline & Security & 6.0 \\
\hline & Gastronomic offer & 5.3 \\
\hline & Basic services & 5.0 \\
\hline & Tourist information & 3.9 \\
\hline & Tourist signage & 4.6 \\
\hline & Training courses & 5.3 \\
\hline & Access to new technologies & 5.0 \\
\hline & Sanitary facilities & 1.8 \\
\hline & Infrastructure & 3.5 \\
\hline & Value for money & 1.8 \\
\hline
\end{tabular}

Source: own elaboration based on the output report of the statistical program IBM-SPSS Statistics v. twenty.

From the statistical results detailed in the preceding table, it is highlighted that, among the principal motivations to visit the gastronomic attraction, the food purchase is distinguished, which includes 55 visitors with a percentage value of $19.5 \%$. Another representative attribute is the peace and quiet that is enjoyed integrated to the gastronomic offer with the vote of 16 respondents and represents one (5.7\%). Next, the recreation variable is located as tourist offering in each one of the selected cantons in the investigation that includes the valuation of 39 consulted; it represents (13.8\%). Finally, the attribute of the gastronomic offer is distinguished with the opinion of 142 visitors with (50.4\%); it represents the highest percentage value, from the total studied among male and female visitors comparatively.

Following with the analysis of the results, regarding the Chi-square test application that is described in Table 4, a confidence coefficient of $95.0 \%$ has been used, therefore, the significance level defined is $5.0 \%(0.05)$. In this regard, it is observed that the relationship of the variables corresponding to gender and motivations to visit the gastronomic delights considering the budget classification of average expenses in low, medium and high, allows us to specify the following. In the budget classification of low, the value of the Pearson's Chi-square is 9.515, with ten degrees of freedom; it is higher than the tabulated value in the table of 9.34. Thus, the null hypothesis is rejected, this suggests that there are significant differences at the level of $\alpha$; therefore, they are not independent variables. For 
Table 3. Contingency table that relates the variable gender and the different motivations to visit the gastronomic attractiveness.

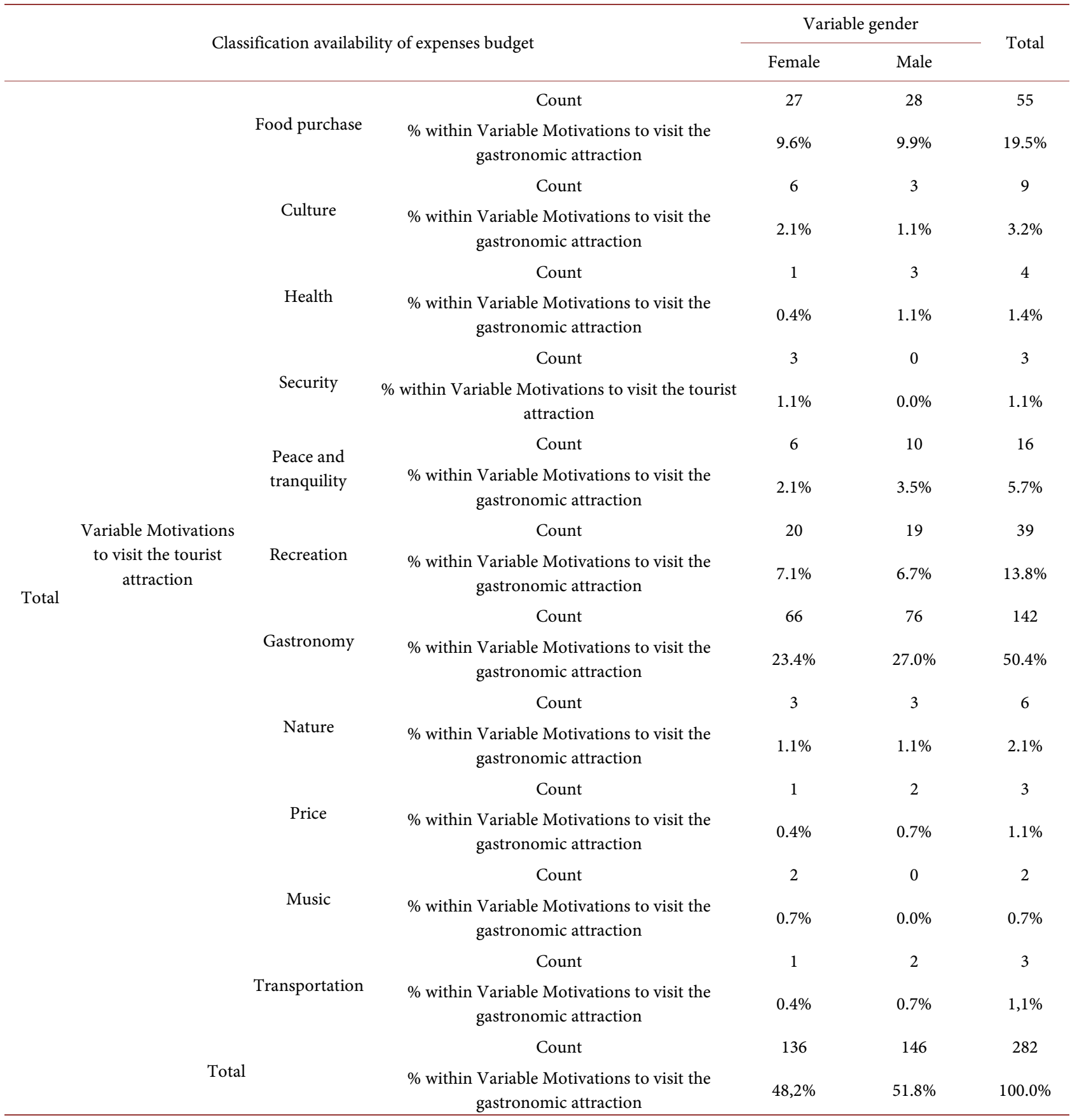

Source: own elaboration based on the output report of the statistical program IBM-SPSS Statistics v. twenty.

the medium budget classification, the calculated value is 5.833 , with seven degrees of freedom, lower than the tabulated value of 6.35 , for that reason, the null hypothesis is accepted, therefore, there are no significant differences between the variables under study at the level of the $\alpha$ value; for the high budget classification of expenses, it is observed that the value obtained from the data processing is 6.836 , with six degrees of freedom. Being this the case, the null hypothesis is rejected; this indicates that there is a significant difference at the level of $\alpha$ value in 
Table 4. Significance values of the Chi-square test according to classification of the availability of expenditure budget.

\begin{tabular}{|c|c|c|c|c|}
\hline \multicolumn{5}{|c|}{ The Chi-square test } \\
\hline \multicolumn{2}{|c|}{ Classification availability of expenses budget } & Value & $\mathrm{df}$ & $\begin{array}{l}\text { Asymptotic significance } \\
\text { (bilateral) }\end{array}$ \\
\hline \multirow{4}{*}{ Availability of low budget } & Pearson Chi-square & $9.515^{\mathrm{b}}$ & 10 & 0.484 \\
\hline & Reasonableness & 11.356 & 10 & 0.330 \\
\hline & $\begin{array}{l}\text { Linear association by } \\
\text { linear }\end{array}$ & 0.309 & 1 & 0.578 \\
\hline & $\mathrm{N}$ of valid cases & 108 & & \\
\hline \multirow{4}{*}{$\begin{array}{c}\text { Availability of average } \\
\text { budget }\end{array}$} & Pearson Chi-square & $5.833^{\mathrm{c}}$ & 7 & 0.559 \\
\hline & Reasonableness & 7.777 & 7 & 0.353 \\
\hline & $\begin{array}{c}\text { Linear association by } \\
\text { linear }\end{array}$ & 0.010 & 1 & 0.921 \\
\hline & $\mathrm{N}$ of valid cases & 76 & & \\
\hline \multirow{4}{*}{ High budget availability } & Pearson Chi-square & $6.836^{\mathrm{d}}$ & 6 & 0.336 \\
\hline & Reasonableness & 8.760 & 6 & 0.188 \\
\hline & $\begin{array}{c}\text { Linear association by } \\
\text { linear }\end{array}$ & 2.373 & 1 & 0.123 \\
\hline & $\mathrm{N}$ of valid cases & 98 & & \\
\hline \multirow{4}{*}{ Total } & Pearson Chi-square & $9.072^{\mathrm{a}}$ & 10 & 0.525 \\
\hline & Reasonableness & 11.082 & 10 & 0.351 \\
\hline & $\begin{array}{c}\text { Linear association by } \\
\text { linear }\end{array}$ & 0.193 & 1 & 0.660 \\
\hline & $\mathrm{N}$ of valid cases & 282 & & \\
\hline
\end{tabular}

relation to the analyzed variables. Finally, in the report of the statistic program results, it is observed in the Total section, a value of 9.072 with ten degrees of freedom, lower than the tabulated 9.34, thus, the null hypothesis is accepted and suggests that there are no significant differences at the a level between the two selected variables.

It must be highlighted that the Chi-square test shows the relationship between the gender variable and the motivation to visit the gastronomic attraction, considering the detailed visitor's expenses budget classification. It has been shown that there is a relationship between the variables under study, for the case in which the budget classification is medium and in the analysis of totals of the applied statistical test.

As previously stated, the article's objective is to characterize a set of socio-psychological variables that can be considered as more important when they describe the profile of the gastronomic visitor. It can contribute to the improvement of the food and drink offering in the cantons selected for the research. For that purpose, the Main Components Analysis is used, a multivariate technique that allows the joint treatment of the observed variables, reducing the number of data and being able to identify a group of fictitious variables formed from the 
combination of the previous ones. Thereby, it is possible to synthesize the data and relate them to each other without making any previous hypothesis about what each initial factor means.

Table 5 shows the statistics corresponding to the study of the sample adaptation to the model. It is verified that the sample adaptation to this analysis is not only desirable, but also presents a very good adaptation to the data, since the KMO statistic indicates the proportion of variance that the analyzed variables have in common, presents a value of 0.619 , coefficient of acceptable value for this type of analysis, this would indicate a perfect adaptation of the data to a factor analysis model. Using Bartlett's sphericity test, we can assure that, if the critical level is higher than 0.05 , thus, the null hypothesis of sphericity should not be rejected. It is verified in the analysis that the significance is perfect, since it obtains the value 0.000 , for this reason, the null hypothesis can be rejected, considering the variables adaptation by means of the suitable factorial analysis.

It is justified that, once all the variables have been introduced, the data obtained offers us a positive definite matrix; this is a necessary condition to be able to continue with the main Component Analysis methodology.

Table 6 shows the matrix of rotated components, where the values situated above 0.5 are exposed, thereby achieving a better explanation of the initial variables obtained for each component. After that, it proceeds to rename the components based on the initial variables that incorporate:

Component 1 . This component includes the set of attributes that are concentrated in the survey, which belong to the group of Motivations, number of people and budget expenses availability, for the gastronomic attraction enjoyment, and constitutes the component that is called Factor Budget, explains by itself, no less than $49.6 \%$, very close to half of the total variance, occupying the first place prominently compared to the rest of the components that must be analyzed as follows.

Component 2. Contains three initial variables that enable to name this component as Repeat Intention Factor, which is related to the level of satisfaction and the gastronomic attraction visit frequency; finally, the variable referred to with the willingness to visit again the offering of food and beverages, where 8.9\% of the total variance is explained.

Component 3. It includes the characteristics that distinguish vocational training, and therefore, its labor integration in the public and private sector has named this component, Knowledge and Employability Factor, explaining by itself, $7.5 \%$ of the total variance.

Component 4: This factor is compound of four variables: the way in which the gastronomic visitor travels, the media consulted, main offerings of another type, integrated to the gastronomic attraction and suggestions for the gastronomic service improvement, this component is called the Factor of Communication and gastronomic offering improvement, since this factor includes the most technical characteristics, explaining $5.7 \%$ of the total variance. 
Table 5. Test of KMO and Bartlett.

\begin{tabular}{ccc}
\hline \multicolumn{2}{c}{ Kaiser-Meyer-Olkin measure of sampling adequacy } & 0.619 \\
\hline & Approx. Chi squared & 1002.970 \\
Bartlett's sphericity test & gl & 78 \\
& Sig. & 0.000 \\
\hline
\end{tabular}

Source: own elaboration based on the output report of the statistical program IBM-SPSS Statistics v. twenty.

Table 6. Component matrix.

\begin{tabular}{|c|c|c|c|c|}
\hline & \multicolumn{4}{|c|}{ Component } \\
\hline & 1 & 2 & 3 & 4 \\
\hline Variable Academic Formation & 0.312 & & 0.685 & -0.269 \\
\hline Variable Occupation & & & 0.696 & 0.326 \\
\hline Variable Travel with & & & 0.445 & 0.596 \\
\hline Variable Number of people accompanying it & 0.576 & & & 0.435 \\
\hline Variable Media consulted regarding the attractiveness & 0.225 & -0.177 & 0.348 & 0.551 \\
\hline Variable Motivations to visit the tourist attraction & 0.592 & 0.119 & -0.142 & \\
\hline $\begin{array}{l}\text { Variable Main offers of another type integrated to the } \\
\text { gastronomic appeal }\end{array}$ & & & & 0.514 \\
\hline $\begin{array}{l}\text { Variable Satisfaction with the offer of services in the } \\
\text { attractiveness }\end{array}$ & -0.222 & 0.787 & & 0.169 \\
\hline Variable Budget of expenses & 0.929 & 0.156 & -0.136 & -0.118 \\
\hline Variable Suggestions for improving the service & 0.105 & -0.307 & -0.271 & 0.556 \\
\hline Variable Frequency of visit to the attractive & & 0.568 & 0.237 & 0.222 \\
\hline Variable I would revisit the gastronomic attraction & -0.122 & 0.752 & 0.109 & \\
\hline Variable Availability classification budget & 0.928 & 0.172 & -0.127 & -0.116 \\
\hline
\end{tabular}

Source: own elaboration based on the output report of the statistical program IBM-SPSS Statistics v. twenty.

As it has been verified, the analysis of main components allows us to discover and prioritize the variables that characterize the gastronomic offering. Moreover, the components identification, allows us to know the aspects, on which it must be influenced by public and private institutions, as well as, the gastronomic services suppliers, also achieving, encouraging the number of potential visitors, improving the satisfaction and repetition index.

It is observed that tourists and visitors, in a general sense, express that this type of gastronomic offer, in its integration must be improved, from the own potentialities that in the tourism field are identified in the territory, the aspect of the security of local customers and visitors requires a program of action, with the participation of social actors, public and private institutions, in order to promote the values of the typical gastronomy, as a motivation to visit the locality and to strengthen the restoration, as well as the increase of accommodation capabilities to meet demand during holidays and vacations. 


\section{Conclusions}

From the research development and once the instruments elaboration process, collection, processing and analysis of the results derived from the applied surveys have finished, a set of conclusions are described as follows:

1) In the gastronomic visitor profile characterization, among the main motivations, the following is highlighted: the purchase of food, the peace and tranquility enjoyed in each of the cantons in relation to the supply of food and beverages. Another aspect to be highlighted is the recreation and leisure options, which are integrated into the culinary service, and finally, the main attraction, the traditional and typical food that distinguishes the tourist activity in the selected locations.

2) Visitors who come to the cantons of Ambato, Baños and Mocha motivated by the gastronomic offering, are characterized by a medium economic level, from higher education preferably, who visit those places as a result of friends and family recommendation, preferably the male gender, public and private sector employees, travel with their family. Besides, the frequency of visits is sometimes in the year, satisfaction with the food and beverages offering with a high percentage value, the willingness to spend on products consumption and gastronomic services offered above $\$ 20.00$ per capita, as well as, the willingness to visit again the gastronomic tourist attraction.

3) It is important that the different public and private administrations, with responsibilities in the tourism sector, coordinate their actions with the aim of improving the supply of gastronomic services, develop strategies in order to reinforce the visitor's most, as well as the least socio-psychological valued variables, in relation to the rest of tourism products and services integrated to the main attraction and positively influence the assessment of the perceptions of tourists who visit these referenced cantons.

4) Based on the different suggestions made by the respondents in the research development, it is necessary to develop a communication and promotion program of the culinary product that is offered in these locations, as well as, its gastronomic importance, that incent the number of new visitors arrivals, with the purpose of preservation, recreation and responsible tasting of this new tourist modality, for the improvement of the economic activity and the family income of the providers of this type of service in the territory.

\section{Translated to English by}

Wilson Fabián Criollo Erazo, wilsonfabice@hotmail.com, University of the Armed Forces ESPE-ESFORSE, Ambato, Ecuador.

Harold Giovanni Lopez Urquizo, B.B.A., Lopez23@bellsouth.net, Florida International University-Miami, Florida, USA.

\section{Conflicts of Interest}

The authors declare no conflicts of interest regarding the publication of this paper. 


\section{References}

[1] Millán, G. (2012) Análisis del turismo gastronómico en la provincia de Córdoba. Tourism \& Management Studies, 8, 79-87. http://www.redalyc.org/html/3887/388743870009/

[2] Leal, M. (2013) Turismo gastronómico y desarrollo local en Cataluña: el abastecimiento y comercialización de los productos alimenticios. $\mathrm{PhD}$. Thesis, Universitat de Barcelona, $\mathrm{V}$.

[3] Torres, E. (2013) Línea conceptual y filosófica de la gastronomía en tiempos del turismo. Jornadas Profesionales Turismo y Gastronomía, Sevatur-Donostia, 16-18. http://www.industria.ejgv.euskadi.eus/r44-00014/es/contenidos/informacion/8013/e s_2598/adjuntos/tb4_03.pdf

[4] Organización Mundial de Turismo (2012) El turismo gastronómico, oportunidad para revitalizar y diversificar la oferta. Hosteltur Magazine, December 2012. http://www.hosteltur.com/121860_turismo-gastronomico-oportunidad-revitalizardiversificar-oferta.html

[5] Huertas, T., et al. (2016) Gastronomic Festivals: Attitude, Motivation and Satisfaction of the Tourist. British Food Journal, 119, 267-283.

https://doi.org/10.1108/BFJ-06-2016-0246

[6] González, S. (2014) El papel de las Estrellas Michelín en el Turismo gastrómano español. Análisis de la guía Michelín y comportamiento del turista. Proyecto Máster Universitario en Dirección y Planificación del Turismo. Universidad de Oviedo, España, 66.

[7] Escuela Universitaria de Turismo de Murcia (2012) El turismo. Conceptos, definiciones e importancia actual, España, 7. https://es.slideshare.net/PLPR4/turismolc

[8] Flores, S. (2013) Perfil del turista nacional que consume alimentos durante Semana Santa en Mazatlán, Sinaloa. Universidad Autónoma de Durango, Campus Mazatlán. Magazine Turismo y Praxis, No. 13, 59-81.

[9] Clave, S. (2012) Gastronomía, turismo y mundialización. https://slidex.tips/download/gastronomia-turismo-y-mundializacion

[10] Silva, E. (2012) Descubriendo el marketing gastronómico. Escuela online de marketing gastronómico.

http://www.puromarketing.com/27/14602/descubriendo-marketing-gastronomico.h $\underline{\mathrm{tml}}$

[11] Palais, R. (2012) Plan de marketing de turismo gastronómico 2012-2016. Instituto Nacional de Promoción Turística, Argentina.

http://cf.cdn.unwto.org/sites/all/files/pdf/plan_de_marketing_de_turismo_gastrono mico.pdf

[12] Chan, A. (2015) The Impact of Tour Service Performance on Tourist Satisfaction and Behavioral Intentions: A Study of Chinese Tourists in Hong Kong. Journal of Travel \& Tourism Marketing, 32, 18-33. https://doi.org/10.1080/10548408.2014.986010

[13] Gomes, A. and Gomes de Sousa, M. (2013) El sistema de oferta de restaurantes de alta gastronomía. Una perspectiva sensorial de las experiencias de consumo. Estudios y perspectivas en Turismo, 22, 336-356. http://www.scielo.org.ar/pdf/eypt/v22n2/v22n2a09.pdf

[14] Montesinos, A. (2013) Definición Productos Gastronómicos y Turísticos: Diseño, Gestión y Venta en Iberoamérica.

https://cegaho.wordpress.com/2016/07/05/productos-gastronomicos-y-turisticos-di seno-gestion-y-venta-en-iberoamerica/ 
[15] de la Torres, V. and Agudo, E. (2010) El turismo gastronómico y las denominaciones de origen en el sur de España: Un estudio de caso. Revista de turismo y patrimonio cultural, 8, 91-101. https://www.redalyc.org/articulo.oa?id=88112836008

[16] Ávila, A.R. (2012) Lagastronomía y su importancia como recurso cultural para el desarrollo del turismo en México. Proyecto de tesis de Maestría. Escuela Superior de Turismo/Sección de Estudios de Posgrado e Investigación Instituto Politécnico Nacional. México, 23.

[17] Hawkins, Best \& Coney (2008) Comportamiento del consumidor. construyendo estrategias de marketing. McGraw Hill, México, 7.

[18] Kotler and Armstrong. (2008) Fundamentos de marketing. (Séptima edición). Editorial PEARSON, México, 128.

[19] Instituto de Estadística y Cartografía de Andalucía (2018) Encuesta de coyuntura turística de Andalucía. Perfil y características del turista. España, 106.

http://www.juntadeandalucia.es/turismoycomercio/.../143447758

[20] Quito Turismo (2015) Caracterización del turismo receptor en el DMQ. https://www.google.com/url?sa=t\&rct=j\&q=\&esrc=s\&source=web\&cd=1\&cad=rja\& uact=8\&ved=2ahUKEwiCz-OWuvHgAhXGIDQIHUlEBA0QFjAAegQIAxAC\&url =https $\% 3 \mathrm{~A} \% 2 \mathrm{~F} \% 2 \mathrm{Fwww} . q u i t o-$ turismo.gob.ec\%2Findex.php $\% 2 \mathrm{Fes} \% 2 \mathrm{Festadisticas}$ \%2Fdatos-turisticos-adicionales $\% 2 \mathrm{~F}$ category\%2F11-gasto-y-perfil-del-turista\%3Fdo wnload\%3D439\%3Aperfil-turista-receptor-en-el-dmq-2015\&usg=AOvVaw1_51WR Bf9IUyFcAaQ8IUG5

[21] Oliveira, S. (2006) La importancia de la Gastronomía en el Turismo. Instituto Politécnico, 216. http://www.scielo.org.ar/pdf/eypt/v16n3/v16n3a01.pdf

[22] PromPerú. (2011) Perfil del Turista Extranjero 2010. http://intranet.promperu.gob.pe/IMPP/2010/TurismoReceptivo/Demanda\%20Actu al/Perfil\%20del\%20Turista\%20Extranjero\%202010/Publicaci\%C3\%B3n\%20PTE\%2 02010.pdf

[23] Mincetur. (2007) Memoria anual 2007 Ministerio de Comercio Exterior y Turismo. http://transparencia.mincetur.gob.pe/documentos/newweb/Portals/0/Memoria_Mi ncetur_2007.pdf

[24] Pat, L.A., et al. (2012) Caracterización del perfil turístico en un destino emergente. Caso de estudio: Ciudad del Carmen, Campeche, México. Gestión turística, $\mathrm{N}^{\circ} 18$, julio-diciembre, 47-70. http://www.redalyc.org/articulo.oa?id=223326490002

[25] Hernández, R. (2006) Metodología de la investigación. Editorial McGrawHill Iberoamericana, México D.F., 329.

http://186.46.158.26/ojs/index.php/EPISTEME/article/view/345

[26] Bermúdez, I. and Rodríguez, R. (2011) Sistema de información turístico. http://www.eumed.net/rev/turydes/05/gpgr.htm

[27] Huertas, T., et al. (2015) El turismo gastronómico en el cantón Mocha. Un estudio del perfil de su demanda. III Congreso Científico Internacional UNIANDES.

https://www.uniandes.edu.ec/web/wp-content/uploads/2016/04/El-turismo-gastron \%C3\%B3mico-en-el-cant\%C3\%B3n-Mocha.-Un-estudio-del-perfil-de-su-demanda. .pdf

[28] Huertas, T. and Cuétara, L. (2016) Perfil del cliente gastronómico del cantón Mocha. EPISTEME. Revista digital de Ciencia, Tecnología e Innovación, 3, 7-9. http://186.46.158.26/ojs/index.php/EPISTEME/article/view/345 